\title{
THE IMPLEMENTATION OF EMOTIONAL AND SPIRITUAL QUOTIENT IN ISLAMIC RELIGIOUS EDUCATION IN SMA NEGERI 20 PANGKEP
}

\section{Ruhul Yusuf, Muhammad Yaumi, Muhammad Khalifah Mustami \\ Pascasarjana UIN Alauddin Makassar}

Email: ruhulyusuf7@gmail.com,muhammad.yaumi@uinalauddin.ac.id, muhkhalifahmustami@uin-alauddin.ac.id

\begin{abstract}
The purpose of this study is to determine the implementation of emotional and spiritual quotients in learning Islamic religious education at SMA Negeri 20 Pangkep. This type of research is descriptive qualitative with a phenomenological and pedagogical-psychological approach. The location of this research is SMA Negeri 20 Pangkep in class $\mathrm{X}$. The data source is the primary data of all Islamic religious education teachers, while the secondary data is RPP documents related to the object under study. Data obtained through observation, interviews, and documentation, then data processing using the Milles and Huberman model (data reduction, data presentation, and conclusion) with analysis using triangulation to ensure data validity against the focus under study. The results of this study indicate that the implementation of emotional and spiritual quotient in Islamic religious education learning at SMA Negeri 20 Pangkep is an Islamic religious education learning activity in which several emotional and spiritual quotient indicators are integrated, including; managing self-emotion, empathy, building relationships (relations), meaning and high self-awareness. This concept is combined by the Islamic religious education teacher at SMA Negeri 20 Pangkep in implementing Emotional and Spiritual quotients.
\end{abstract}


Keyword: Emotional, Spiritual, Islamic Religious Education

\section{Preliminary}

Humans are creatures created by Allah SW'T who are equipped with various potentials that are not owned by other creatures. Namely the potential for reason, with human intelligence, many tools is created that facilitate all activities, whether in the form of household tools, transportation, communication, and so on. These various discoveries are part of the results of the potential for reason, or popularly known today as intellectual intelligence (Intelligence Quotient) which is also supported by other potentials.

In achieving success, the potential for Intelligence Quotient (IQ) in humans must be supported by other potentials. There are many assumptions that state that when someone has a high IQ, that person has a greater chance of achieving success. But in fact, not a few people fail to achieve success because they only rely on IQ. This has been researched by psychologist Daniel Goleman quoted by Ary Ginanjar Agustian who stated that IQ only has a role of around $20 \%$ in determining the success and success of a person's life, while the remaining $80 \%$ is determined by other 
factors including emotional intelligence (Emotional Quotient). or commonly abbreviated as EQ. ${ }^{1}$

Today there are three integrated human bits of intelligence known as a supporting factor for success. The three bits of intelligence in question have been stated previously, namely IQ and EQ, spiritual intelligence (Spiritual Quotient). IQ is intelligence that emphasizes a person's ability to solve problems on the potential of reason. EQ is the ability to recognize one's own emotions, regulate or manage emotions, motivate yourself, recognize other people's emotions, and build relationships with others. ${ }^{2}$ Meanwhile, a Spiritual Quotient (SQ) is a person's ability to manage and interpret spiritual values in his life. ${ }^{3}$ Ideally, the three bits of intelligence must be integrated and integrated into humans so that they guide success.

$\mathrm{IQ}, \mathrm{EQ}$, and $\mathrm{SQ}$ have an equally important charge to synergize with each other. In the book entitled Multiple Intelligences Learning (Multiple Intelligences) by Muhammad Yaumi and Nurdin Ibrahim it is said that spiritual intelligence

${ }^{1}$ Daniel Goleman, "Emotional Intelligence," in Ary Ginanjar Agustian, The Secret to Success in Building Emotional and Spiritual Intelligence, ESQemotional spiritual Quotient, vol. 1 (Jakarta: Arga Wijaya Persada, 2001), p. 56.

${ }^{2}$ Mubin, "The Concept of Emotional and Spiritual Intelligence (ESQ) in Al-Ghazali's Sufism Perspective." Thesis, (Banjarmasin: IAIN Antasari, 2004), p. 2

${ }^{3}$ Mubin, "The Concept of Emotional and Spiritual Intelligence (ESQ) in the Perspective of Sufism Al-Ghazali." Thesis, p. 4. 
is a term used to show that $\mathrm{SQ}$ is correlated with EQ. ${ }^{4}$ Ary Ginanjar also emphasized that $\mathrm{SQ}$ is the highest intelligence of humans, the foundation needed to function IQ and EQ effectively. ${ }^{5}$ For example, the corruptors, of course, are people who have a high IQ and EQ, but their IQ and EQ are not supported by SQ so that actions that harm themselves and others are born.

The concept of intelligence IQ, EQ, and SQ in education has relevance to the three domains that are the goals of education, by Benjamin S. Bloom, which is commonly known as Bloom's Taxonomy. The three domains are the cognitive domain, affective domain, and psychomotor domain. IQ has a very close relationship with the cognitive domain which emphasizes the thought process, while EQ is closely related to the affective domain which emphasizes the aspects of feelings and emotions, such as interests, attitudes, perceptions, and ways of conforming, while SQ is closely related to the psychomotor domain, the abilities that generated by human motor functions in the form of readiness, perception, guided response, and creation.

EQ and SQ which are synergized into an integrated unit were introduced by Ary Ginanjar as spiritual emotional

${ }^{4}$ Muhammad Yaumi and Nurdin Ibrahim. Learning Based on Multiple Intelligences (Cet. II; Jakarta: Prenadamedia Group, 2016), p. 205.

${ }^{5}$ Ary Ginanjar Agustian, The Secret to Success in Building Emotional and Spiritual Intelligence, ESQ emotional spiritual Quotient, vol. 1 (Jakarta: Arga Wijaya Persada, 2001), p. 14. 
intelligence (Emotional Spiritual Quotient) abbreviated as ESQ. ${ }^{6}$ ESQ is an amalgamation of ideas, between EQ ideas and SQ ideas, or the ability to build effective human relationships and interpret every behavior and activity as worship. Therefore, someone who has a good Emotional and Spiritual Quotient will be able to establish good social relationships, the behavior and activities he carries out always contain meaning and is based on good values.

Education is the right place to create humans who have good Emotional and Spiritual Quotient. This was also emphasized by A. Ramaraju, who stated that education is a forum for developing humans to lead an effective and meaningful life. ${ }^{7}$ The government, the private sector, industry, and society in general, have the same expectations of the output of each level of education. Starting from primary, secondary, to tertiary education, it is hoped that it can produce people who are beneficial to themselves and others. In the observations made by researchers, it is known that one of the teachers of Islamic religious education at SMA Negeri 20 Pangkep, integrates Emotional and Spiritual Quotient in each of his learners.

${ }^{6}$ Ary Ginanjar Agustian, The Secret to Success in Building Emotional and Spiritual Intelligence, ESQ emotional spiritual Quotient, vol. 1, h. 11-14.

${ }^{7}$ A. Ramaraju, "A Study On Emotional Quotient Vs Intelligence Quotient Of Management Students," International Journal of Management (IJM), vol. 6 no. 4 (April 2015), h. 59. https://pdfs. semanticscholar. org/6ace/736e8aa1b399b6eb58b61a0aa49e441a3ad2. pdf (Diakses 14 Januari 2019). 


\section{Theoretical Review}

\section{Emotional Quotient (EQ)}

The definition of intelligence still produces different understandings based on the placement of the intelligence context. It is more emphatically stated that intelligence is contextual. ${ }^{8}$ Even though there is an overlap regarding the definition of intelligence, there is an implied understanding that when a person is intelligent, he is capable of solving the problems at hand. So that skills in solving the difficulties faced are a minimum requirement, something can be said to be a form of intelligence. Whatever the context, ${ }^{9}$ when a person has the skills to solve the difficulties he is facing, then that person can be said to be intelligent.

As for emotion, it is visible from daily actions, sourced from feelings, both sad and happy feelings. It is more widely stated that mental agitation such as anger, sadness, fear, pleasure, surprise, irritation, shame, and love is also part of the emotion. ${ }^{10}$ Emotion also refers to its characteristic feelings and thoughts, a biological and psychological state, and a set of

8 Taufik Fasaik, IQ / EQ / SQ Revolution; Uncovering the Secret of Intelligence Based on the Koran and the Latest Neurosaics (Bandung: PT Mizan Pustaka, 2008), p. 22-26.

${ }_{9}^{9}$ Muhammad Yaumi and Nurdin Ibrahim. Multiple Intelligences Based Learning (Cet. II; Jakarta: Prenadamedia Group, 2016), p. 9-11.

${ }^{10}$ Hamzah B. Uno, A New Orientation in Learning Psychology (Jakarta: Bumi Aksara, 2012), p. 64-65. 
tendencies to act. ${ }^{11}$ For example, when a mother dies, on the one hand, there is a child who cries for her mother hysterically, and on the other hand, there is a child who is only sad without hysterical crying. Thus, whether an action is born or accompanied by emotional turmoil can be called an emotion.

The simple description of EQ, intelligence, and emotions above is not far from a person's ability to control the feelings that are being experienced. A psychologist Daniel Goleman asserts that emotional intelligence, namely; one's ability to motivate oneself and to cope with frustration, control impulses and not exaggerate pleasures, regulate moods and keep the burden of stress from stifling the ability to think, as well as to empathize and pray. ${ }^{12}$ So that when you hear the word emotional intelligence, at least the essence of the word must be remembered, namely a person's psychic ability, both in controlling one's feelings and in establishing good relationships with other people.

\section{The characteristics of a person having a high EQ}

An intelligent person, especially emotionally intelligent certainly has characteristics as an indicator that he

11 Daniel Goleman, Emotional Intelligence, trans. T Hermaya, Emotional Intelligence (Jakarta: PT Gramedia Pustaka Utama, 2017), p. 109.

12 Daniel Goleman, Emotional Intelligence, trans. T Hermaya, Emotional Intelligence, p. 43. 
is emotionally intelligent. The following are some of the characteristics of an emotionally intelligent person, as follows:

a. Always think positively and remain optimistic in the life process. ${ }^{13}$

b. Skilled in building one's own emotions and recognizing the emotions of others. ${ }^{14}$

c. Having creativity, intentionality, and toughness. ${ }^{15}$

d. Compassion or empathy, intuition, and integrity. ${ }^{16}$

e. Conscious of quality of life and optimal performance. ${ }^{17}$

So someone who has high emotional intelligence is indeed true, this has been proven through many studies, including research conducted by Natalie L. Shipley, Mary Jo Jackson, and Sharon Larisa Segrest, whose research specifications are on the effects of emotional intelligence on age, work experience. , and academic achievement. The results of his research prove that when a person has high emotional intelligence, work performance and academic achievement are much better. ${ }^{18}$

13 Casmini, Emotional Parenting (Yogyakarta: Pilar Medika, 2007), p. 24.

14 Paul Hendri, Emotional and Spiritual Intelligence (Jakarta: Publisher Arga, 2001), p. 41.

15 Hamzah B Uno, Managing Intelligence in Learning (Jakarta: PT. Sawo Raya, 2009), p. 18.

16 Casmini, Emotional Parenting, p. 24.

${ }^{17}$ Casmini, Emotional Parenting, p. 25.

${ }^{18}{ }^{18}$ Natalie L, all., "The effects of emotional intelligence, age, work experience, and academic performance," Research in Higher Education 
As described above, people who have a high EQ can recognize the emotions of themselves and others, so they know how to behave and act with careful consideration. They tend to have high empathy for others, easy to get along with, communicate and seek good relationships with others.

\section{Spiritual Quotient (SQ)}

Something that comes to mind when hearing the word SQ is religious intelligence, or obedience to worship, such as prayer, fasting, zakat, and so on, but it turns out that this is not entirely true. It turns out that SQ is not only dedicated to religious intelligence, or is limited to obedience to worship God. ${ }^{19}$

The root word spiritual is the spirit which means spirit. This word comes from the Latin word spiritus, which means breath. Spirit can be interpreted as a motor of motion, something that makes people live and move and feel various tastes. ${ }^{20}$ Spiritual is also known as nature, everything outside the physical, including thoughts, feelings, and characters. ${ }^{21}$ thus it can be stated that the spiritual dimension of man is a

$\begin{array}{llll}\text { Journal. } & \text { (Januari } & \text { 2010). } & \text { h }\end{array}$ http://www.aabri.com/manuscripts/10535.pdf (Diakses 7 Juli 2018).

19 Danah Zohar and Ian Marshall, Spiritual Intelligence (Bandung: Mizan, 2007), p. 7-9.

${ }^{20}$ Abu Muhammad Iqbal, al-Gazali's Concept of Thought About Education, p. 235-236.

${ }^{21}$ Ki Hajar Dewantoro, "Education," in Muhammad Yaumi and Nurdin Ibrahim, Multiple Intelligences-Based Learning (Cet. II; Jakarta: Prenadamedia Group, 2016), p. 22. 
supernatural dimension, the energy which enables man to live, move and feel something.

SQ focuses on the three-dimensional relationship of humans. The three-dimensional relationship in question is the relationship between humans and fellow humans, the relationship between humans and nature, and the relationship between humans and God. This is in line with the definition of SQ which has been explained in the Big Indonesian Dictionary that SQ is intelligence concerning the heart and care between fellow humans, other creatures, and the environment based on the belief in the existence of God Almighty. ${ }^{22}$ Therefore, it is not surprising to say that spiritual intelligence is a complete picture to complement the various human intelligence.

The term spirituality attached to SQ suggests that this intelligence rests on the inside of humans, to be precise on the human conscience. The human conscience always guides him to have high awareness, holiness, meaning, and produce something of value. Suharsono emphasized that spiritual intelligence rests on human nature, the actualization of nature itself. $^{23}$ Therefore, this intelligence grows from nature, the human conscience itself to produce something of value.

22 Indonesia Dictionary. (On line). Available at KBBI. Kemdikbud.go.id/ entries / Religious. (Accessed 10 Apri 2018).

23 Suharsono, Launching IQ, IE, \& IS (Jakarta: Press Initiation, 2004), p. 160. 
The explanation above further clarifies the understanding that spiritual intelligence (SQ) is an abstract intelligence but can be observed through the symptoms it causes, connecting the ratio with emotions, mind, and body, and focusing on the problem of the meaning of each behavior or activity carried out. Therefore, for someone who is spiritually intelligent, his behavior or activities, actions, or way of life are part of the solution.

\section{SQ characteristics}

What appears to be the characteristics of spiritual intelligence are as follows.

a. Clear principles and guidelines for life, based on universal truth.

Clear principles and guidelines for life, which are based on universal truth. ${ }^{24}$ This is a strong guideline for behavior. Sometimes someone experiences doubt about what to do, this is because there is no clear principle and guide for life, and something they do is not based on universal truth.

b. A high level of consciousness

24 Toni Buzan, The Power of Spiritual Intelligence: 10 Ways to tap into your spiritual genius, trans. Ana Budi Kuswandani, The Power of ESQ: 10 Steps to Improve Emotional, Spiritual Intelligence (Indonesia: PT. Pustaka Delapratosa, 2003), p. 6 
High level of consciousness. ${ }^{25} \mathrm{High}$ awareness in the sense of having a level of awareness that you don't know yourself excessively and can control yourself from negative behavior.

\section{c. Make sense}

The third characteristic is interpreting. ${ }^{26}$ Assuming everything that happens has to value so that it leads to the submission of the soul in high dedication. To interpret something means to give high and positive treatment to everything.

\section{d. Reluctant to disturb or hurt.}

Reluctant to disturb or hurt. ${ }^{27} \mathrm{~A}$ spiritually intelligent person will not harm other beings and nature. Feeling that the universe is one unit when disturbing anything and anyone, it will eventually return to oneself.

\section{Islamic Education}

The definition of education with its totality in the Islamic context is inherent with the connotations of the terms tarbiyah, ta lim, and ta dib. ${ }^{28}$ Tarbiayah the verb rabba

25 Abd. Wahab and Umiarso, Educational Leadership and Spiritual Intelligence (Yogyakarta: Ar-Ruzz Media, 2010), p. 47.

${ }^{26}$ Danah Zohar and Ian Marshall, Spiritual Intelligence, p. 16-32.

${ }^{27}$ Agus Neranto, Quantum Quotient (Quantum Intelligence): Quick Ways to Increase IQ, EQ, and SQ Harmoniously (Bandung: Publisher Nuansa, 2001), p. 57.

${ }^{28}$ Dzakiah Drajad et al., Islamic Education (Cet. XII; Jakarta: PT Bumi Aksara, 2016). h. 25-27. 
(Educate) is used in the Qur'an, one of which is in QS al-Isra / 17: 24. Its emphasis is on nurture and guidance, covering body, mind, and soul, which is carried out continuously with love. love, gentleness, and care. There is ta lim whose verb allama means to teach. The emphasis is on the effort to transfer knowledge and train the skills of students from ignorance to knowledge.

Regarding the meaning of Islamic religious education, experts have contributed their thoughts. Among them; Zakiyah Daradjat said that Islamic religious education is an effort to foster and nurture students so that they can always understand Islamic teachings as a whole to practice and make Islam a way of life. ${ }^{29}$ Then Zuhaerini together with several colleagues agreed to state that Islamic religious education is a systematic and pragmatic effort in helping students so that they live according to Islamic teachings. ${ }^{30}$ Furthermore, Ahmad Tafsir stated that Islamic education is the guidance given by a person so that he can develop optimally according to Islamic teachings. ${ }^{31}$ Even though the various definitions are varied, it is clear that the common point is that Islamic religious education leads to a process of forming the

29 Abd.MajiddanDian Andayani, Competency-Based Islamic Religious Education: Concept and Implementation of the 2004 Curriculum (Bandung: PT Rosdakarya, 2004), p. 130.

30 Zuhaerini, Special Methods for Religious Education (Cet. VIII; Surabaya: Scientific Bureau, 1983) h. 27.

31 Ahmad Tafsir, Islamic Education, p. 43. 
personality of students so that they have an Islamic personality.

By paying attention to some of the descriptions above, it can be concluded that Islamic religious education is a conscious effort in the form of guidance, both physical and spiritual for students according to Islamic teachings, as a life guide for them to achieve happiness in the world and the hereafter. In the sense of all efforts so that students can recognize, understand, live the faith, have faith and have good character and practice Islam from its main source, namely the holy books of al-Qur'an and al-Hadith.

Purpose of Islamic Religious Education

In its implementation, the goals of education can be divided into three qualifications that must be achieved by students. First, the qualification of knowledge, Islamic religious education is expected to be able to increase students' religious insight so that students can understand various knowledge about Islam. The two qualifications are skills, namely students are expected to have skills in the implementation of various acts of worship following the guidance of al-Qur an and al-Hadith. The three qualifications of attitude, students are expected to have a good personality, the personality in question is the personality that has been exemplified by Muhammad. The three qualifications are each adjusted to the level of education of the students. so that the 
purpose of Islamic religious education lies in two specific objectives. $^{32}$

\section{Research Methodology}

This research uses qualitative research. This research aims to analyze and describe phenomena, events, social activities, attitudes, beliefs, perceptions, individual and group thoughts. ${ }^{33}$ The approach used is phenomenological and pedagogical, in processing data and analyzing data, researchers used Milles and Huberman's model of data reduction, data presentation, and concluding. ${ }^{34}$ As for the primary data sources for Islamic education teachers at SMA Negeri 20 Pangkep and secondary data using books, journals, research results, and documentation related to the research title.

\section{Results and Discussion}

The results of the study, namely the implementation in question, is the integration of several emotional and spiritual quotient indicators in Islamic religious learning at SMA Negeri 20 Pangkep, including managing self-emotions, empathy, building relationships, inner direction, high self-

${ }^{32}$ Ahmad Tafsir, Education in Islamic Perspective, (Bandung: Youth Rosda Karya), p. 16.

${ }^{33}$ Nana Syaodih Sukmadinata, Educational Research Methods (Bandung: PT. Remaja Rosdakarya, 2007), h. 60.

${ }^{34}$ Nana Syaodih Sukmadinata, Educational Research Methods (Bandung: PT. Remaja Rosdakarya, 2007), h. 60. Miles and Huberman, Qualitative Data Analysis, in Sugiyono Educational Research Methods: Quantitative Approaches, Qualitative, and R \& D, p. 244. 
awareness. The subject matter is discussed in the following sub-chapters:

1. Managing Self-Emotions Integrated in Islamic Religious Education Learning in SMA Negeri 20 Pangkep

Managing one's own emotions begins with recognizing one's own emotions, one's awareness of the psychological conditions that are being experienced. Such people have a higher sensitivity to their feelings, are always aware of their moods, because if they are less alert they become overpowered and easily dissolved in negative emotions such as sadness, fear, and anxiety. Therefore, before implementing learning, teachers and students should recognize their psychological conditions, know the emotional state they are experiencing.

The process of recognizing self-emotion which is integrated into Islamic religious education learning at SMA Negeri 20 Pangkep can be seen from the information provided by the Islamic religious education teacher, Pak Ridwan, as follows.

The learning process does not only require clarity of mind, but the psychological element must also be clarified, and meanwhile, how do we want to clear something up if we don't know what to clarify. So we must first recognize the feelings we experience before starting lessons, lest we as a teacher be in a negative emotional state, such as anger or sadness, or our 
students who are sad or afraid. For example, when some students arrive late that day and get social sanctions for cleaning the school toilets, of course, that day they will feel embarrassed and sad, the shame and sadness they experience will interfere with their attitude in learning, so these negative emotions must be recognized. The trick is to pause together with the students while closing their eyes and trying to feel the mood they are experiencing at that time. So in essence, before starting lessons, we as teachers and students should recognize the emotional conditions we experience at that time, especially negative emotions such as feelings of sadness, fear, anxiety, and so on. ${ }^{35}$

Through the statement of the Islamic religious education teacher above, it is known that before starting learning, teachers and students are strived to recognize the emotional conditions experienced at that time through a moment's silence, while closing their eyes and trying to feel the mood they are experiencing. The statement given by Pak Ridwan, was seen that he directed his students to pause for a moment while closing their eyes and trying to recognize the mood they were experiencing. The two learning actors try to identify the psychological atmosphere they feel before entering the learning process, especially in negative emotions

35 Muhammad Ridwan (29 years), Islamic Religious Education Teacher at 20 Pangkep Public High School, Interview, Pangkep 9 September 2019. 
such as sadness, fear, and anxiety, by pausing for a moment while closing their eyes and trying to feel the mood they are experiencing at that time.

Pak Ridwan reiterated that when negative emotions reign in the teacher or students, such as anxiety, sadness, and fear, the mind or brain cannot think clearly, which in turn will have an impact on learning. ${ }^{36}$ It is undeniable that of the many students who want to take part in classroom learning, not all of them have a good emotional atmosphere, such as being happy and happy. Sometimes some of them bring sadness from their homes or fear because they don't do an assignment, or even worry about a lesson they find difficult. The anxiety, sadness, or fear they experience greatly affects their learning attitudes and ultimately harms the learning process or outcome they will achieve.

After Ridwan and the students recognized the emotions they felt, they then managed those emotions. Managing emotions is the ability to be able to entertain themselves when negative emotions arise, a condition in which a person does not dissolve from these emotions in the sense of trying to find a balance of the emotions experienced, harmonizing heart, mind, and feelings. The steps taken by Mr. Ridwan in terms of managing emotions after recognizing their own emotions can be found through the following statement:

${ }^{36}$ Muhammad Ridwan (29 years), Islamic Religious Education Teacher at 20 Pangkep Public High School, Interview, Pangkep 9 September 2019. 
Managing my own emotions is termed by clearing my heart. So every time I want to start learning, I and the students first clear my mood. From the process of recognizing our own emotions, we continue to read (just a whisper) ta'awudz and istigfar several times, we do this for 10 to 20 seconds. Ta'awudz means that we are asking for protection from Allah SWT. From Satan's temptations because of the source of negative emotions from Satan's temptations. As for istigfar, it is a form of remorse for mistakes that have been committed which cause negative emotions from Satan's temptations such as anxiety, fear, and restlessness. After that, I will lead the students to read several verses of the Qur'an. The recitation of several verses of the Qur'an will treat restlessness of the heart, as Allah says that the Koran is shifaan (medicine). Thus, whispers of ta'awudz, istigfar, and chanting of the verses of the Koran will clear the mood, thereby drowning out negative emotions such as fear, anxiety, and sadness. ${ }^{37}$

Based on the above statement, it is known that the method used by Mr. Ridwan in terms of managing selfemotion in learning after recognizing self-emotion is by clearing the mood through the whisper of ta'wudz, istigfar 10 to 20 seconds, and reading several verses of the Qur'an.

37 Muhammad Ridwan (29 years), Islamic Religious Education Teacher at 20 Pangkep Public High School, Interview, Pangkep 9 September 2019. 
Ta'awudz means a form of asking for protection from Allah SWT. From Satan's temptations because of the source of negative emotions from Satan's temptations. As for istigfar, it is a form of remorse for mistakes that have been committed which cause negative emotions from Satan's temptations such as anxiety, fear, and restlessness. As for the recitation of several verses of the Qur'an will treat restlessness of the heart.

Negative emotions such as fear, anxiety, sadness, and anxiety are managed with whispers of ta'awudz, istigfar, and chanting of the verses of the Qur'an. It was seen that Pak Ridwan and all the students were silent, closed their eyes while whispering ta'awudz and istigfar and after that, they opened their eyes and read several verses of the Qur'an. The classroom atmosphere at that time was calm and comfortable. Thus, it is known that the method used by Pak Ridwan as an effort to manage self-emotion which is integrated with Islamic religious education learning, namely, cannot be separated from efforts to drown negative emotions such as fear, anxiety, and sadness, or in what he calls clear moods. through whispers of ta'awudz, istigfar, and chanting of the verses of the Qur'an.

2. Empathy Integrated with Learning Islamic Religious Education at SMA Negeri 20 Pangkep

Among the manifestations of empathy are caring and compassion, mutual respect, and the desire to help others. All can be observed when someone can understand (understand) what others are experiencing and feeling. Students who can 
empathize tend to have a clear desire to be wise about the decisions that they will make, be courteous to their friends, and act with humility towards all their actions, in short, always take into account the feelings or emotions of others and take well into account - bad of the action to be performed.

The empathy that is integrated into learning Islamic religious education at SMA Negeri 20 Pangkep can be seen from the information provided by the Islamic religious education teacher, Pak Ridwan, as follows.

One of the ways that I do to instill a sense of empathy for students is by telling the life problems experienced by one of the students in front of his friends. So at the first meeting, I gave the assignment to all students to write down a story or true story about the life problems they experienced, this assignment they wrote on a sheet of paper which they would collect at the next meeting, At each meeting, I would bring up a story or true story about the life problems of a student in front of the class without mentioning the identity of the actor in the story or story. Through stories or stories of life problems experienced by fellow students, I hope that a sense of empathy will grow in them. I do this for 5-10 minutes at the beginning of the lesson, and sometimes the 
stories or stories that I raise connect with the learning theme that will be learned that day. ${ }^{38}$

Through the statement put forward by Mr. Ridwan above, it is clear that fostering a sense of empathy in students, is done by providing a stimulus in the form of stories or real stories about life problems experienced by their classmates. Real stories or stories about life problems experienced by students are used as a stimulus to foster a sense of empathy in students.

The stimulus to foster a sense of empathy for students in the form of stories or stories about life problems from students itself is proven to be able to generate a sense of empathy.

Thus it can be concluded that the method taken by Mr. Ridwan in instilling a sense of empathy in learning Islamic religious education at SMA Negeri 20 Pangkep is by stimulating the form of stories or stories about life problems from fellow students themselves.

For the feeling of empathy to grow, Pak Ridwan also made other efforts. This method can be seen from the following statement:

${ }^{38}$ Muhammad Ridwan (29 years), Islamic Religious Education Teacher at 20 Pangkep Public High School, Interview, Pangkep 9 September 2019. 
In the learning process, arguments often occur between students, or just simply expressing opinions in front of their friends. Students who want to listen to arguments or opinions conveyed by their friends until they finish without interrupting their words, then that is a simple picture of cultivating empathy which will give birth to a form of empathy in the form of caring, compassion, and mutual respect. I accustom students to enthusiastically listen to the opinions expressed by their friends, especially during the presentation of work results, even though some disagree with the results of the work delivered, they still give opportunities to friends whose percentages complete what is said. Likewise, when there is a rebuttal given to the presentation that has been presented, the percentage remains enthusiastic about listening to the rant given without interrupting or cutting words until the rebuttal is finished, and so on until the end of the presentation. And what is no less important is getting students accustomed to giving appreciation to each of the arguments their friends have put forward. ${ }^{39}$

Through Pak Ridwan's statement above, it is known that the way he has taken so that a sense of empathy grows in students is through habituation of listening, listening, without

${ }^{39}$ Muhammad Ridwan (29 years), Islamic Religious Education Teacher at 20 Pangkep Public High School, Interview, Pangkep 9 September 2019. 
cutting other people's conversations to completion and giving a mutual appreciation of other people's opinions or arguments. Through this habituation, they will grow in them a form of empathy in the form of caring, compassion, and mutual respect. So it can be concluded that in instilling a sense of empathy to students, it is not necessary to directly tell them to care, be compassionate, respectful, and help each other, but indirectly it can be done politely as practiced by Islamic religious education in SMA 20 Pangkep.

3. Fostering Relationships (Relationships) which are integrated into Islamic Religious Education Learning in SMA Negeri 20 Pangkep

Humans are social creatures who need other people in the process of their life, without a good relationship, then human life will not go well. Even so in the school environment, especially in the classroom. In the classroom, a good relationship (relationship) must be created between fellow class members, be it a good relationship (relationship) between educators and students, as well as good relationships (relations) between students and other students so that the learning process takes place well.

Fostering a good relationship (relationship) cannot be separated from good interactions between individuals. For example, when you want to build a good relationship (relationship) in the family environment, you need good interaction between family members. Likewise, fostering good relationships (relations) in the classroom takes good 
interaction between class members, both interactions between students and other students, as well as interactions between students and educators. Thus it can be said that in building good relationships, good interactions are needed.

As for fostering relationships (relations) that are integrated with Islamic religious education learning at SMA Negeri 20 Pangkep, it can be seen from the information given by the Islamic religious education teacher, Pak Ridwan, as follows.

Sometimes some teachers position themselves "higher" than students, they put an unnatural distance between them and their students, this is what makes some teachers behave arrogantly in serving students as if in class only teachers want to be understood and appreciated by students. This is the first thing I have to get rid of, I have to build good relationships with students. I must call students with good vocations, such as Adinda Ahmad or Ade Ahmad. Especially when giving instructions, I try to use the word invitation instead of the command word, such as; let's work on it, let's listen to it, let's watch it, let's see and so on. I always say the words please and thank you to the students. Everything I do to these students becomes an example to them, gradually it will produce a close emotional 
bond so that the relationship between me and students is well established. ${ }^{40}$

Based on what Pak Rdwan has stated above, fostering relationships that are integrated with learning Islamic religious education at SMA Negeri 20 Pangkep is integrated with the use of words or sentences that are good in interacting with students. The words or sentences in question are: first, calling students with good calls such as Adinda Admad or Ahmad's younger brother. Second, using a call-to-action sentence in giving instructions, such as let's do it, let's listen, let's look at it, let's see, and so on. Apart from that, in interacting with students Mr. Ridwan also did not hesitate to use the words please and thank you.

Apart from the information that has been stated by Mr. Ridwan above, Mr. Ridwan also fosters good relationships (relations) between students through debate forums in class.

Debate is a fight of opinion on a problem by giving reasons to defend each other's opinion. So that debate sometimes becomes one of the reasons for a relationship (relationship) that is not well-developed because there are words, sentences, or attitudes that I think are good for the participants in the debate. On the

40 Muhammad Ridwan (29 years), Islamic Religious Education Teacher at 20 Pangkep Public High School, Interview, Pangkep 9 September 2019. 
other hand, I make use of the debate form between students in the class to build a good relationship between them. So the first is to realize that the debate forum is not a forum to seek victory but a forum to find the truth, then when they are arguing, I remind them to respect their friends' opinions even though there are differences of opinion, use polite words or sentences, do not exalt voice, and called his friend with a good call such as; brother, sister, brother Ahmad, sister Rezki. Through this habituation, they will be trained, and a good relationship (relationship) will be established between them. ${ }^{41}$

Through the above statement, it is known that Mr. Ridwan uses the debate process between students in the class to build a good relationship (relationship) between them. Because there is argumentation in the debate process, sometimes it makes debate participants do various ways to defend their arguments, so it is not uncommon for us to meet debate participants who use words, sentences, or bad attitudes to bring down their opponent, debates like this are what Pak Ridwan said. will make a bad relationship (relationship) occur between students. Through the aforementioned statement, it was also known that before students began to argue, Mr.

41 Muhammad Ridwan (29 years), Islamic Religious Education Teacher at 20 Pangkep Public High School, Interview, Pangkep 9 September 2019. 
Ridwan made his students aware that the debate forum was not a forum to seek victory but a forum to seek the truth, inviting students in the debate to respect their friends' opinions despite differences. opinion invites to use polite words or sentences, does not raise his voice, and calls his friends with good calls such as; brother, sister, brother Ahmad, sister Rezki. Through this habituation, students will be trained, and a good relationship will be developed between them.

Apart from that, the researchers also saw that Mr. Ridwan also did not hesitate to say the words please and thank you to his students. The debate process that occurs in the classroom is also very conducive, there is mutual respect among students, there is no dropping each other between them, the debate process seems to be used as a process to enrich or increase their knowledge to find a bright spot on a problem.

The steps mentioned above are the methods taken by Mr. Ridwan so that students are trained in building good relationships, be it the relationship between educators and students, as well as relationships between fellow students in establishing interactions.

4. Interpretation which is integrated with the learning of Islamic religious education at SMA Negeri 20 Pangkep

Spiritual intelligence is intelligence, one of which focuses on the issue of meaning or value. Doing a job or 
responsibility with full sincerity and dedication. As an example of a profession as a teacher, when a person experiences his profession as a teacher, it is only limited to job demands and aborting obligations, the teacher is not yet able to interpret his profession as a teacher. However, when a teacher undergoes his profession as a teacher based on a calling to educate students through learning, guidance, and training, the teacher is classified as a teacher who can interpret his profession as a teacher. Thus, interpreting is an action that is driven based on the human conscience.

As for the interpretation that is integrated into learning Islamic religious education at SMA Negeri 20 Pangkep, it can be seen from the information given by the Islamic religious education teacher, Mr. Ridwan, as follows.

As we all know that Islamic religious education subjects are compulsory subjects at every level of education. Islamic religious education is studied for 6 years in elementary school, then 3 years of junior high school in 3 years of high school, so a total of 12 years. However, it cannot be denied that there are still many students who have graduated from high school who do not know the Koran, do not know the prayer, do not know how to bathe obligatory, even many of them have deviant morals. What is it about the Islamic religious education they have learned? where is the result? It cannot be denied that many factors cause all of this to occur, among them, the students have not been able to 
interpret their orientation in studying Islamic religious education learning materials. As for the way I make it so that students can interpret their orientation in learning Islamic religious education learning materials, namely by strengthening the learning objectives. How, after I convey the theme of the learning material, and before I convey the learning objectives, I ask students to ask their conscience, what should I understand from the material? and what should I do after understanding the material? The two questions will direct students to interpret every action they will take in the learning process and after the learning process ${ }^{42}$

Based on what has been stated by Mr. Rdwan above, related to the meaning that is integrated with Islamic religious education learning at SMA Negeri 20 Pangkep is integrated through strengthening learning objectives. The beginning of learning begins by conveying the theme of the learning material, after which students are asked to ask their conscience, what should be understood from the material? and what to do after understanding the material? The two questions the participants asked before Mr. Ridwan directed the students to interpret every action they would take in the learning process and after the learning process.

42 Muhammad Ridwan (29 years), Islamic Religious Education Teacher at 20 Pangkep Public High School, Interview, Pangkep 9 September 2019. 
Learning Islamic religious education at SMA Negeri 20 Pangkep is integrated through strengthening learning objectives. Before entering into the core of learning, the teacher conveys the theme of the learning material, after students know the learning theme, the teacher asks students to ask two questions to their conscience. The two questions in question are: First, what should I understand from the material? Second, what should I do after understanding the material? So whatever the theme of learning that students will learn, they must ask their conscience that, what should I understand from the material.

As a conclusion from the results of the interview from Mr. Ridwan as the Islamic religious education teacher at SMA Negeri 20 Pangkep, it is known that the interpretation that is integrated into learning Islamic religious education at SMA Negeri 20 Pangkep is carried out through strengthening learning objectives.

5. High Self-Awareness Integrated in Islamic Religious Education Learning in SMA Negeri 20 Pangkep

Self-awareness is a very important first step for students to know their abilities, and to change. Students who have high self-awareness can know who they are. Through self-awareness, students can know themselves in various situations and circumstances, including the conditions of their intellectual abilities. Thus, in the end, it will make it easier for students to prepare all the things that support learning. 
Self-awareness of students has not formed automatically but there is an effort that is made, in this class the business can be pursued in various ways. The method taken by Mr. Ridwan in cultivating high self-awareness in students can be seen from the statement below.

By familiarizing students with completing assignments and tests based on their work. However, in the process of completing assignments or daily tests, different from the process of completing assignments and tests in general, students will be grouped in pairs, consisting of two people, each of whom will be responsible for supervising and checking the results of their friends' work. Through efforts like this, every student will; first, be accustomed to honesty and responsibility, because they are the ones who supervise and examine the work of their friends. Second, being aware of their abilities, they will see directly from their friends the work that has been checked to find out where their shortcomings are. Third, realizing what is being done, monitoring, and checking the results of friends 'work is a very big responsibility because it involves the "fate" of other people who are in our hands, so that little by little students' self-awareness will be formed. ${ }^{43}$

${ }^{43}$ Muhammad Ridwan (29 years), Islamic Religious Education Teacher at 20 Pangkep Public High School, Interview, Pangkep 9 September 2019. 
Based on what has been stated by Pak Ridwan above and the results of research by researchers in the classroom, that the high self-awareness integrated into learning Islamic religious education at SMA Negeri 20 Pangkep is done by accustoming students to completing assignments and tests based on their work. However, in the process of completing tasks or daily tests, different from the process of completing tasks and tests in general, they will be grouped in pairs, consisting of two people who each will be responsible for supervising and checking the results of their friends' work. Through efforts like this, every student will; first, be accustomed to honesty and responsibility, because they are the ones who supervise and examine the work of their friends. Second, being aware of their abilities, they will see directly from their friends the work that has been checked to find out where their shortcomings are. Third, realizing what is being done, supervising, and checking the results of friends 'work is a very big responsibility because it involves the "fate" of other people who are in our hands, so that little by little students' self-awareness will be formed.

In conclusion, the high self-awareness integrated into Islamic religious education learning at SMA Negeri 20 Pangkep is carried out by accustoming students to completing assignments and tests based on their work results. However, in the process of completing tasks or daily tests, different from the process of completing tasks and tests in general, they will be grouped in pairs, consisting of two people who each will be responsible for supervising and checking the results of 
their friends' work. Thus it is known that students' selfawareness can be formed through the efforts of teachers in the classroom, such as the efforts made by Pak Ridwan.

\section{Conclusion}

As for the results of the authors 'conclusions from this study, namely managing self-emotion which is integrated into learning Islamic religious education at SMA Negeri 20 Pangkep is carried out by explaining the students' mood through the whispers of ta'awudz, istigfar 10 to 20 seconds, and reading several verses of the Qur'an an, Empathy which is integrated into learning, habituation of listening, listening, without interrupting friends' conversations to completion and giving mutual appreciation of opinions and arguments and fostering relationships (relations) which are integrated into Islamic religious education learning. Interpreting which is integrated into learning Islamic religious education at SMA Negeri 20 Pangkep is carried out through strengthening learning objectives. And high self-awareness integrated into Islamic religious education learning at SMA Negeri 20 Pangkep is done by getting students to complete assignments and tests based on their work results.

\section{References}

A. Ramaraju, (2015) "A Study On Emotional Quotient Vs Intelligence Quotient of Management Students," 
International Journal of Management (IJM), vol. 6 no. 4 April.)

Abd. Wahab and Umiarso, (2018) Educational Leadership and Spiritual Intelligence (Yogyakarta: Ar-Ruzz Media.)

Agustian, Ary Ginanjar. (2001) The Secret to Success Building Emotional and Spiritual Intelligence, ESQ emotional spiritual Quotient, vol. 1 (Jakarta: Arga Wijaya Persada).

Andayani, Abd.Majid and Dian. (2014) Competency-Based Islamic Religious Education: Concept and Implementation of the 2004 Curriculum (Bandung: PT Rosdakarya).

Buzan, Toni. (2018) The Power of Spiritual Intelligence: 10 Ways to tap into your spiritual genius, trans. Ana Budi Kuswandani, Strengths of ESQ: 10 Steps to Improve Emotional, Spiritual Intelligence (Indonesia: PT. Pustaka Delapratosa).

Dzakiah Drajad et al., (2016) Islamic Education (Cet. XII; Jakarta: PT Bumi Aksara)

Dewantoro, Ki Hajar. (2016) "Education," in Mubammad Yaumi and Nurdin Ibrabim, Multiple Intelligences-Based Learning (Cet. II; Jakarta: Prenadamedia Group).

Fasaik, Taufik. (2008) IQ / EQ / SQ Revolution; Uncovering the Secret of Intelligence Based on the Qur'an and the latest Neurosciences (Bandung: PT Mizan Pustaka).

Goleman, Daniel. (2001) "Emotional Intelligence," in Ary Ginanjar Agustian, The Secret to Success in Building Emotional and Spiritual Intelligence, ESQemotional spiritual Quotient, vol. 1 (Jakarta: Arga Wijaya Persada). 
---------. (2017) Emotional Intelligence, trans. T Hermaya, Emotional Intelligence (Jakarta: PT Gramedia Pustaka Utama).

Hamzah B Uno, (2019) Managing Intelligence in Learning (Jakarta:

PT. Sawo Raya.)

Ibrahim, Muhammad Yaumi and Nurdin. (2016) Learning Based on Multiple Intelligences (Cet. II; Jakarta: Prenadamedia Group).

Indonesia Dictionary. (2018) (Online). Available at KBBI. Kemdikbud.go.id/ entries / Religious. (Accessed April 10).

Mubin, (2004) "The Concept of Emotional and Spiritual Intelligence (ESQ) in Al-Ghaqali's Sufism Perspective." Thesis, (Banjarmasin: IAIN Antasari).

Marshall, Danah Zohar and Ian. (2007) Spiritual Intelligence (Bandung: Mizan).

Miles and Huberman, Qualitative Data Analysis, in Sugiyono Educational Research Methods: Quantitative, Qualitative, and $R$ \& Approaches,

Natalie L, all., (2018) "The effects of emotional intelligence, age, work experience, and academic performance," Research in Higher Education Journal. January http://www.aabri.com/manuscripts/10535.pdf (Accessed 7 July 2018).

Neranto, Agus. (2001) Quantum Quotient (Quantum Intelligence): A Quick W ay to Power Up IQ, EQ, and SQ Harmoniously (Bandung: Publisher Nuansa). 
Neranto, Agus. (2001) Quantum Quotient (Quantum Intelligence): A Quick Way to Power Up IQ, EQ, and SQ Harmoniously (Bandung: Publisher Nuansa).

Suharsono, (2018) Launch IQ, IE, \& IS (Jakarta: Press Initiation).

Sukmadinata, Nana Syaodih. (2007) Educational Research Methods (Bandung: PT. Remaja Rosdakarya).

Uno, Hamzah B. (2012) A New Orientation in Learning Psychology (Jakarta: Earth Literacy).

Zuhaerini, (1983) Special Methods for Religious Education (Cet. VIII; Surabaya: Scientific Bureau). 